Науковий вісник НЛтУ України
Scientific Bulletin of UNFU
https://nv.nltu.edu.ua
$\begin{gathered}\text { https://doi.org/10.15421/40290515 } \\ \text { Article received 24.05.2019 p. } \\ \text { Article accepted 30.05.2019 p. } \\ \text { Удк 630*53(477.8) }\end{gathered}$

Т. В. Юськевич, Р. Р. Вицега, Г. Г. Гриник

Національний лісотехнічний університет України, м. Львів, Украӥна

\title{
ЗАЛЕЖНІСТЬ ПОКАЗНИКІВ КРОН ВІД МОРФОЛОГО-ТАКСАЦІЙНИХ ПАРАМЕТРІВ ДЕРЕВ ІНТРОДУКОВАНИХ ВИДІВ СОСЕН В УМОВАХ ЗАХІДНОГО РЕГІОНУ УКРАЇНИ
}

\begin{abstract}
Наведено результати дослідження крон соснових інтродуцентів в умовах Західного регіону України. Досліджено деревостани з участю сосни чорної, сосни Веймутова, сосни Банкса, сосни жорсткої та сосни звичайної (контроль). Удосконалено методику таксації крон дерев мішаних деревостанів з використанням ГІC Field-Мар. Проаналізовано закономірності між морфолого-таксаційними параметрами окремих дерева та морфологічними показники їхніх крони. Здійснено розрахунок середніх значень середнього діаметра та висоти стовбура дерева, діаметра крони, висоти іï початку, протяжності крони, іiі проекції, об'єму та площі поверхні, а також об'єму стовбура. Розраховано основні статистики досліджуваних морфолого-таксаційних параметрів і показників дерев. Крім того, здійснено кореляційний аналіз рядів відповідних параметрів і показників та здійснено відбір для можливості моделювання залежності морфологічних показників крон від морфолого-таксаційних параметрів дерев досліджуваних видів сосен. Встановлено, що для моделювання значень площі проекції крони, іії об'єму та площі поверхні крони найпридатнішими є діаметр стовбура та діаметр крони досліджуваних видів сосен. Розроблені моделі залежностей адекватно описують емпіричний матеріал з високим рівнем апроксимації та характеризуються достатньою статистичною достовірністю. Отримані моделі можуть бути основою для створення нормативно-довідкових матеріалів для оцінення щільності компонентів фітомаси крони з використанням відповідних перевідних коефіцієнтів.
\end{abstract}

Ключові слова: крона дерева; сосна жорстка; сосна чорна; сосна Банкса; сосна Веймутова; ГІС Field-Мар; моделювання.

Вступ. Разом із комплексом грунтово-гідрологічних та кліматичних умов на ріст та розвиток деревних рослин має вплив крона, яка фактично формує асиміляційний апарат. Тому для глибшого розуміння процесів формування та накопичення деревини у стовбурі дерева потрібно здійснити аналіз морфологічних показників крон та встановити відмінності між інтродукованими та аборигенними видами сосен. У польових умовах без застосування спеціального обладнання порівняно легко можна визначити такі морфолого-таксаційні параметри стовбура дерева, як висота та діаметр, а також висота до початку крони, іiі протяжність та діаметр. Разом 3 тим на здатність окремого дерева фотосинтезувати відповідний об'єм речовини впливають такі показники крони, як площа ії̈ проекції, об'єм та площа поверхні. Ці показники $з$ достатнім рівнем точності можна визначити за допомогою польової ГІС Field-Map. На основі здійснених вимірювань та обчислень доцільно також здійснити моделювання морфологічних ознак крони дерев досліджуваних видів для подальшого використання під час оцінювання запасів фітомаси та для порівняння продуктивності порід-інтродуцентів 3 місцевими видами, а також для можливості планування та прогнозування лісівничих господарських заходів власне для формування оптимальних умов для росту сосен чорної, жорсткої, Веймутова та Банкса $з$ урахуванням особливостей місцевих типів лісорослинних умов (ТЛУ).

Питання формування крон досліджувало багато як вітчизняних, так і закордонних науковців. Серед закордонних наукових досліджень у цій царині можна умовно виділити два основні напрями: перший - вивчення особливостей висоти початку (прикріплення) крони, другий - дослідження залежностей, які оцінюють частку крони дерева (Davies \& Pommerening, 2008). Окремим напрямом можна виділити моделювання параметрів крон з урахуванням їх просторового розташування та впливу на їх формування таксаційних параметрів дерев (Peper, McPherson \& Mori, 2001; Thorpe et al., 2010). Серед вітчизняних лісівників-науковців варто відзначити роботи, у яких досліджено залежності між морфологічними і таксаційними ознаками для таких деревних порід в умовах Українських Карпат, як: бук лісовий (Ilkiv, 2002), ялина європейська (Hadov, Horoshko \& Korol, 2003) та клен-явір (Pukman \& Hrynyk, 2013); в умовах Подільської Височини - для сосни звичайної (Gromiak, Hrynyk \& Yarosh, 2013; Gromiak et al., 2014; Hrynyk \& Gromyak, 2014); у степових умовах України для робінії звичайної та для сосни звичайної (Sytnyk,

Інформація про авторів:

Юськевич Тарас Васильович, канд. с.-г. наук, доцент, кафедра ботаніки, деревинознавства та недеревних ресурсів лісу.

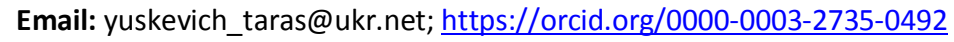

Вицега Руслан Романович, канд. с.-г. наук, доцент, кафедра лісової таксації та лісовпорядкування. Email: vitseha@ukr.net

Гриник Георгій Георгійович, д-р с.-г. наук, доцент, кафедра лісової таксації та лісовпорядкування.

Email: h.hrynyk@nltu.edu.ua; https://orcid.org/0000-0001-7417-5047

Цитування за ДСтУ: Юськевич Т. В., Вицега Р. Р., Гриник Г. Г. Залежність показників крон від морфолого-таксаційних параметрів дерев інтродукованих видів сосен в умовах Західного регіону України. Науковий вісник НЛтУ України. 2019, т. 29 , № 5. С. 75-81.

Citation APA: Yuskevych, T. V., Vytseha, R. R., \& Hrynyk, H. H. (2019). The Dependence of Crown Indicators on Morphological and Taxonomic Parameters of pine trees of Introduced Species in Western Ukraine. Scientific Bulletin of UNFU, 29(5), 75-81. https://doi.org/10.15421/40290515 
Lovynska, Lakyda \& Maslikova, 2018). Проте дослідженнями не охоплені питання щодо крон інтродукованих видів сосни.

Об'єкт дослідження - деревостани 3 домінуванням інтродукованих видів сосен.

Предмет дослідження - взаємозалежність показників крон від морфолого-таксаційних параметрів дерев досліджуваних видів сосен.

Мета дослідження - проаналізувати залежність показників крон від морфолого-таксаційних параметрів дерев інтродукованих видів сосен в умовах Західного регіону України та здійснити їх моделювання.

Матеріали і методика дослідження. Для аналізу соснових деревостанів підібрано ділянки в переважаючих типах лісорослинних умов. У цих насадженнях закладено кругові пробні площі величиною 500-1500 м². Здебільшого пробні площі закладено у центрі біогруп, що сформовані інтродукованими породами. Усі пробні площі закладено з використанням сучасних програмноінструментальних засобів, зокрема польової ГIC FieldMap (використовували технологію Field-Map (IFERMonitoring and Mapping Solutions. S.r.o., www.field-mapping.com), надану НЛТУ України в 2006 р. у рамках програми міжнародного співробітництва Чеської Республіки - проект ТехІнЛіс) (Buksha \& Buksha, 2013; Data Collector, 2006). Згідно 3 методикою робіт виконано картування дерев та вимірювання їх основних таксаційних параметрів. Зокрема для дерев, що ростуть на пробній площі, виконано вимірювання діаметра стовбура на висоті грудей, загальної висоти дерева, висоти початку та найширшої частини крони, горизонтальної проекції крони та тї поздовжнього профілю. Вимірювання останніх показників зумовлено необхідністю визначення об'єму крони окремого дерева. За допомогою навігаційних засобів (GPS-приймачі) зафіксовано координати центрів усіх пробних площ.

Розрахунок основних лісівничо-таксаційних показників пробних площ виконано за загальноприйнятими у лісовій таксації алгоритмами. Натомість об'єм крони дерев визначено за допомогою програмних модулів ГІС Field-Map (Hadov, Horoshko \& Korol, 2003). Основні статистики та коефіцієнти зв'язку між окремими ознаками виконано з дотриманням рекомендацій щодо статистичного аналізу даних в біологічних об'єктах (Horoshko, Myklush \& Khomiuk, 2004; Gromiak, Hrynyk \& Yarosh, 2013; Gromiak et al., 2014; Hrynyk \& Gromyak, 2014).

Результати дослідження. Для оцінення фітомаси деревних порід із загального переліку закладених пробних площ було виділено 10 найхарактерніших, у яких виконано вимірювання низки показників відповідно до наведеної вище методики (Yuskevych, Vytseha \& Osadchuk, 2015; Yuskevych, Huz \& Skrobach, 2013). Лісівничо-таксаційну характеристику пробних площ наведено у табл. 1. За даними цієї таблиці бачимо, що пробні площі закладено у різних за складом деревостанах. Найбільшу кількість пробних прощ (5 шт.) закладено у насадженнях 3 участю сосни Веймутової. Три пробні площі закладено у насадженнях з участю сосни Банкса. При цьому друга пробна площа характеризує одночасно сосну чорну і сосну Банкса, а восьма пробна площа - сосну Банкса і сосну жорстку. Пробні площі відібрано так, щоб частка досліджуваних порід у складі насаджень становила не менше 6 одиниць.
Табл. 1. Лісівничо-таксаційні показники насаджень пробних площ

\begin{tabular}{|c|c|c|c|c|c|c|}
\hline \multirow[b]{2}{*}{$\begin{array}{l}\text { № } \\
\text { ПП }\end{array}$} & \multirow[b]{2}{*}{$\begin{array}{c}\text { Вік, } \\
\text { років }\end{array}$} & \multirow[b]{2}{*}{$\begin{array}{c}\text { Склад } \\
\text { деревостану }\end{array}$} & \multirow{2}{*}{$\begin{array}{c}\text { Абсо- } \\
\text { лютна } \\
\text { повнота, } \\
\text { м }^{2} \text { га }\end{array}$} & \multicolumn{2}{|c|}{ Середні } & \multirow{2}{*}{$\begin{array}{c}\text { Загаль- } \\
\text { ний за- } \\
\text { пас, } \\
\text { м³ }^{3} \text { ra }^{-1}\end{array}$} \\
\hline & & & & $\begin{array}{c}\text { ді- } \\
\text { аметр, } \\
\text { см }\end{array}$ & $\begin{array}{c}\text { ви- } \\
\text { сота, } \\
\text { м }\end{array}$ & \\
\hline 1 & 98 & $10 \mathrm{Cч}+\mathrm{Mд \epsilon}$ & 54,9 & 37,4 & \begin{tabular}{|l|}
19,4 \\
\end{tabular} & 537,0 \\
\hline 2 & 87 & $\begin{array}{c}\text { 6Сж4Сз+Дз, Дч, } \\
\text { Сб, Бб }\end{array}$ & 35,7 & 34,6 & 25,6 & 394,9 \\
\hline 3 & 82 & 8Сб1Дч1Дс & 27,3 & 27,5 & 20,6 & 271,7 \\
\hline 4 & 93 & $\begin{array}{c}6 \mathrm{CB}_{4} \mathrm{C}_{3}+Д 3, \Gamma 3, \\
\text { Бп, Дч }\end{array}$ & 50,3 & 40,7 & 28,4 & 686,6 \\
\hline 8 & 83 & 10Сб+Сж & 29,5 & 25,4 & 23,1 & 338,6 \\
\hline 10 & 77 & 6Сз3Сб1Дз+Дс & 37,5 & 28,7 & 26,1 & 460,2 \\
\hline 11 & 101 & $\begin{array}{c}10 \text { Св+Мде, Гз, } \\
\text { Бкл }\end{array}$ & 80,1 & 51,8 & 40 & 1703,1 \\
\hline 12 & 110 & $\begin{array}{c}\text { 7Св2Сз1Дз+Дч, } \\
\text { Вхс }\end{array}$ & 64,2 & 42,2 & 26,6 & 848,2 \\
\hline 13 & 108 & $10 \mathrm{CB}_{\mathrm{B}}+$ Дч & 101,9 & 68,1 & 38,1 & 1940,8 \\
\hline 14 & 60 & $10 \mathrm{CB}_{\mathrm{B}}$ & 38,6 & 38 & 33,3 & 635,0 \\
\hline
\end{tabular}

На основі поздовжнього профілю крони та їі горизонтальної проекції, які отримують шляхом інструментальних замірів (рис. 1 і 2), розраховано об'єм крони окремого дерева через обчислення визначеного інтегралу об'ємної фігури, що створена просторовим моделювання (Buksha \& Buksha, 2013; Data Collector, 2006).

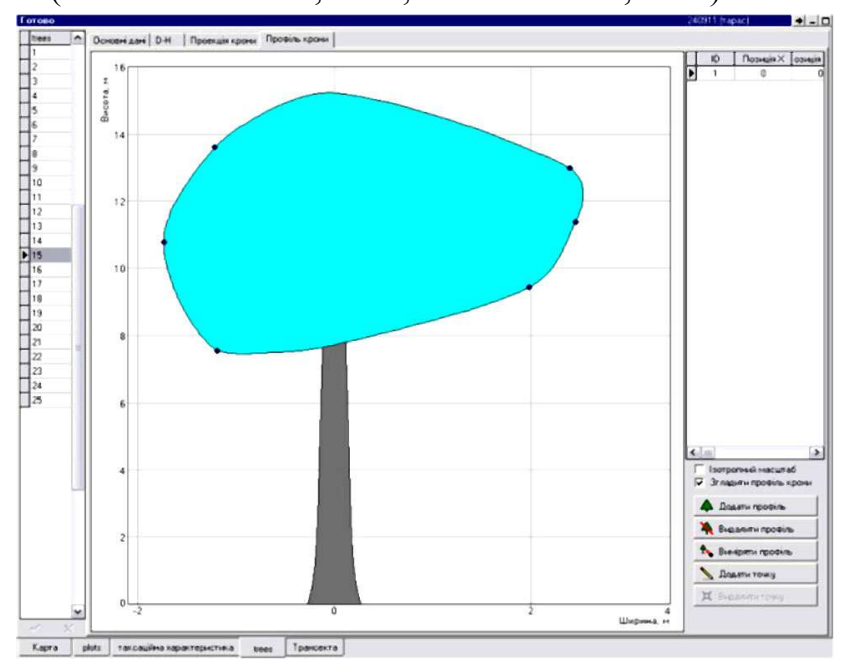

Рис. 1. Поздовжній профіль крони дерева № 15 на ПП-2 у середовищі Field-Map Data Collector

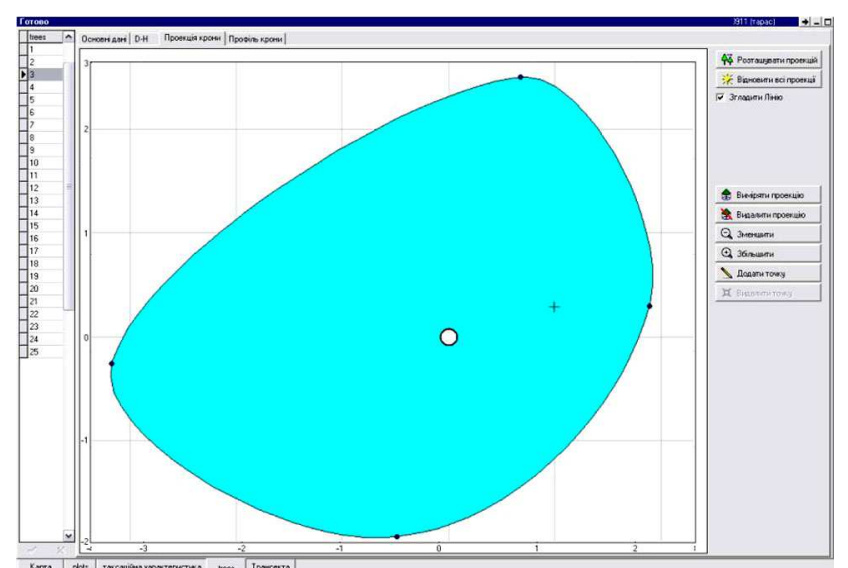

Рис. 2. Горизонтальна проекція крони дерева № 3 на ПП-2 у середовищі Field-Map Data Collector

Власне розрахунок усіх морфологічних характеристик крони виконано в автоматичному режимі. За результатами розрахунку формується база даних з відповідними значеннями атрибутів. Приклад банку даних для другої пробної площі наведено на рис. 3. 


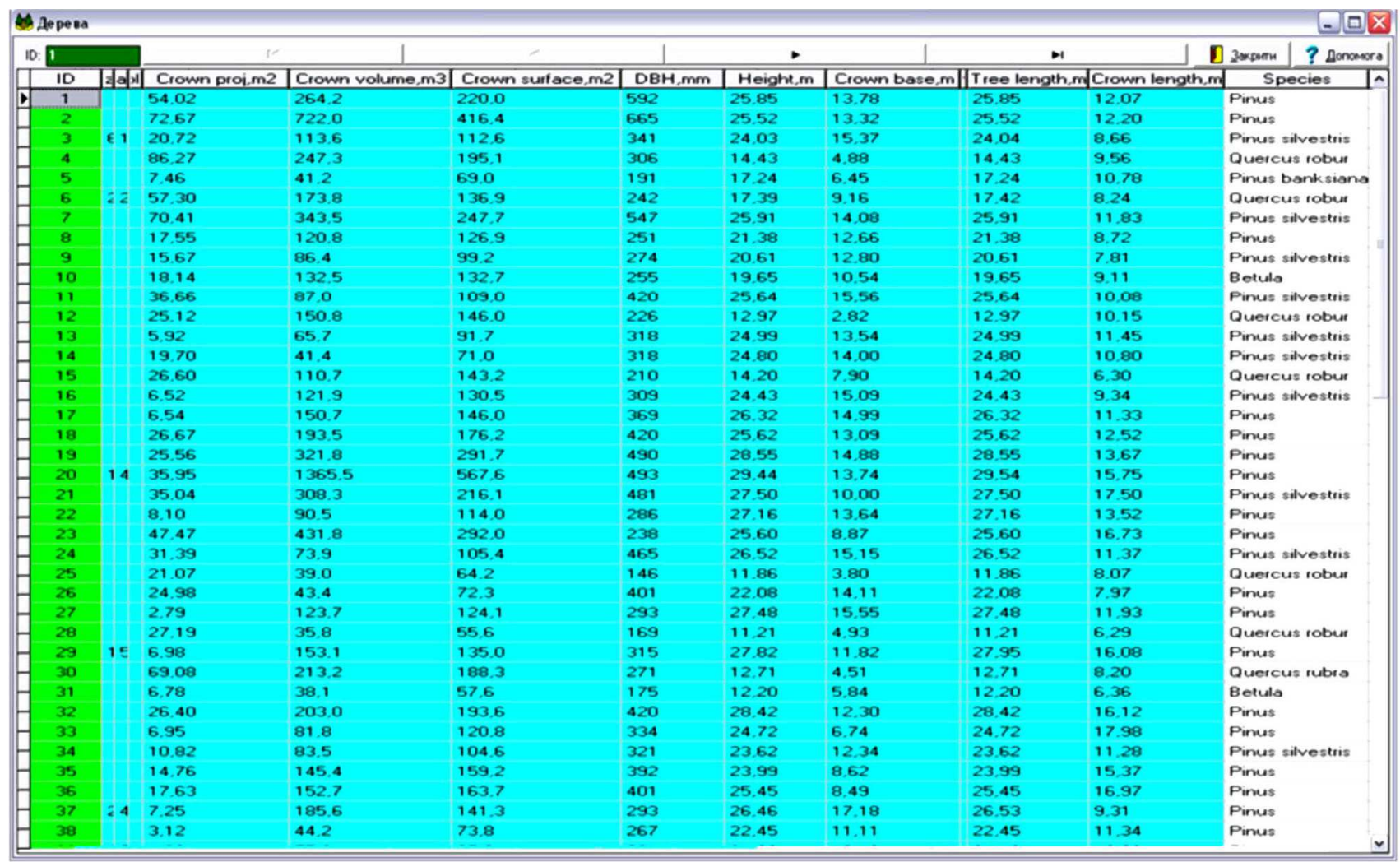

Рис. 3. Банк даних дерев на ПП-2 (фрагмент) у середовищі Field-Map Data Collector

За результатами польових замірів аналогічну інформацію сформовано для усіх пробних площ. Після розрахунків можемо отримати зведені дані щодо певних характеристик крон дерев. Найважливішими показниками крони дерева є площа горизонтальної проекції та об'єм крони. Власне ці показники у розрізі деревних порід для кожної пробної площі (та у перерахунку на 1 га) наведено у табл. 2 .

Табл. 2. Показники крон дерев на пробних площах

\begin{tabular}{|c|c|c|c|c|c|c|}
\hline \multirow{2}{*}{\begin{tabular}{|l|} 
№ \\
ПI
\end{tabular}} & \multirow{2}{*}{ Порода } & \multirow{2}{*}{$\begin{array}{c}\text { Запас } \\
\text { стовбу- } \\
\text { рів, } \\
\text { м } / \text { га }\end{array}$} & \multicolumn{2}{|c|}{$\begin{array}{c}\text { Горизонтальна } \\
\text { проекція крони, } \mathrm{m}^{2}\end{array}$} & \multicolumn{2}{|c|}{ Об'єм крони, м³ } \\
\hline & & & $\begin{array}{c}\text { на } \\
\text { ділянці }\end{array}$ & на 1 га & $\begin{array}{c}\text { на } \\
\text { ділянці }\end{array}$ & на 1 га \\
\hline \multirow{3}{*}{1} & $\mathrm{Cч}$ & 508 & 627,75 & 12555,0 & 2076,30 & $\begin{array}{l}41526,0 \\
\end{array}$ \\
\hline & Мдє & 29 & 19,38 & 387,60 & 72,76 & 1455,0 \\
\hline & Разом & 537 & 647,1 & 12942,6 & 2149,1 & 42981,0 \\
\hline \multirow{7}{*}{2} & Сб & 6 & 18,21 & 121,4 & 119,49 & 796,60 \\
\hline & Бб & 4 & 32,67 & 217,8 & 191,99 & 1279,9 \\
\hline & Сж & 221 & 470,83 & 3138,9 & 6113,08 & 40753,9 \\
\hline & $\mathrm{C} 3$ & 143 & 364,17 & 2427,8 & 1965,43 & 13102,9 \\
\hline & Д3 & 14 & 284,75 & 1898,3 & 865,72 & 5771,5 \\
\hline & Дч & 8 & 189,95 & 1266,3 & 1046,96 & 6979,7 \\
\hline & Разом & 396 & 1360,6 & 9070,5 & 10302,7 & 68684,5 \\
\hline \multirow{4}{*}{3} & Сб & 212 & 180,97 & 3619,4 & 1006,73 & 20134,6 \\
\hline & Дс & 34 & 240,56 & 4811,2 & 595,68 & 11913,6 \\
\hline & Дч & 26 & 197,34 & 3946,8 & 1584,25 & 31685,0 \\
\hline & Разом & 272 & 618,9 & 12377,4 & 3186,7 & \begin{tabular}{|l|}
63733,2 \\
\end{tabular} \\
\hline \multirow{7}{*}{4} & Бб & 10 & 69,82 & 465,5 & 184,168 & 1227,8 \\
\hline & $\Gamma_{3}$ & 24 & 590,13 & 3934,2 & 2163,1 & 14420,7 \\
\hline & Св & 380 & 663,4 & 4422,7 & 4341,46 & 43,0 \\
\hline & $\mathrm{C}_{3}$ & 242 & $\begin{array}{l}571,99 \\
\end{array}$ & 3813,3 & 3360,08 & 22400,5 \\
\hline & Дс & 28 & 169,30 & 1128,7 & 974,35 & 6495,7 \\
\hline & Дч & 3 & 73,71 & 491,4 & 448,22 & 2988,2 \\
\hline & Разом & 687 & 2138,4 & 14255,7 & 11471,4 & \begin{tabular}{|l|l|}
7645,8 \\
\end{tabular} \\
\hline \multirow{3}{*}{8} & Сб & 329 & 538,31 & 10766,2 & 2580,27 & 51605,36 \\
\hline & Сж & 10 & 21,83 & 436,58 & 224,35 & \begin{tabular}{|l|}
4487,02 \\
\end{tabular} \\
\hline & Разом & 339 & 560,1 & 11202,8 & 2804,6 & \begin{tabular}{|l|}
56092,4 \\
\end{tabular} \\
\hline \multirow[t]{2}{*}{10} & Сб & 152 & 347,21 & 6944,14 & 1793,86 & 35877,26 \\
\hline & $\mathrm{C}_{3}$ & 272 & 559,73 & 11194,6 & 2495,49 & 49909,78 \\
\hline
\end{tabular}

\begin{tabular}{|c|c|c|c|c|c|c|}
\hline & Дс & 6 & 118,28 & 2365,64 & 203,90 & 4077,92 \\
\hline & Д3 & 30 & 299,61 & 5992,12 & 926,41 & 18528,26 \\
\hline & Разом & 460 & 1324,8 & 26496,5 & 5419,6 & 108393,2 \\
\hline \multirow{5}{*}{11} & $\Gamma_{3}$ & 7 & 86,03 & 1720,6 & 148,53 & \begin{tabular}{|l|}
2970,60 \\
\end{tabular} \\
\hline & Бл & 7 & 72,768 & 1455,36 & 114,853 & 2297,06 \\
\hline & Мде & 25 & 34,457 & 689,14 & 375,545 & 7510,90 \\
\hline & $\mathrm{CB}_{\mathrm{B}}$ & 1664 & 647,602 & 12952 & 4701,57 & 94031,44 \\
\hline & Разом & 1703 & $\mathbf{8 4 0 , 8 5 7}$ & 16817,1 & 5340,5 & 106810,0 \\
\hline \multirow{6}{*}{12} & Bxc & 4 & 23,727 & 474,54 & 63,55 & 1271,06 \\
\hline & C3 & 200 & 141,89 & 2837,78 & 1069,41 & 21388,24 \\
\hline & $\mathrm{C}_{\mathrm{B}}$ & 549 & 441,11 & 8822,26 & 4060,95 & 81218,94 \\
\hline & Д3 & 78 & 53,61 & 1072,16 & 1592,27 & 31845,32 \\
\hline & Дч & 17 & 29,29 & 585,84 & 230,315 & 4606,3 \\
\hline & Разом & 848 & 689,6 & 13792,6 & 7016,5 & 140329,9 \\
\hline \multirow{3}{*}{13} & Св & 1932 & 524,71 & 10494,2 & 10526,6 & 210531,8 \\
\hline & Д3 & 9 & 41,33 & 826,6 & 216,145 & 4322,9 \\
\hline & Разом & 1941 & 566,0 & 11320,8 & 10742,7 & 214854,7 \\
\hline 14 & $\mathrm{C}_{\mathrm{B}}$ & 635 & 371,1 & 7422,6 & 3097,9 & \begin{tabular}{|c|}
61957,7 \\
\end{tabular} \\
\hline
\end{tabular}

Встановлено, що об'єм крон є дуже мінливим показником і залежить від низки морфолого-таксаційних параметрів як стовбура окремого дерева, так і показників деревостану загалом. Зокрема, об'єм крони сосни Веймутової змінюється у межах 28,9-210,5 тис. м³/га. Об'єм крони сосни Банкса змінюється у діапазоні 20,151,6 тис. ${ }^{3} /$ га (за винятком другої пробної площі, де її частка у складі насадження не перевищує $2 \%$ ). Об'єм крони сосни жорсткої становить 40,8 тис. $\mathrm{m}^{3} /$ га, а сосни чорної - 41,5 тис. $\mathrm{m}^{3} /$ га. Аналогічну тенденцію спостерігаємо за показником маси крони. 3 огляду на значну мінливість об'єму крон вбачаємо за доцільне проаналізувати вплив різних лісівничо-таксаційних показників стовбура і крони на її об'єм. Значення об'єму крон, на відміну від об'єму стовбура, не надає вичерпної інформації щодо іiї практичного використання. Тому важливим показником $є$ маса крони. У подальших дослідженнях плануємо на основі результатів аналізу щільності та об'ємів деревини і кори модельних гілок встановити пе- 
ревідні коефіцієнти, які дадуть змогу на основі відомого значення об'єму крони визначити їі масу для досліджуваних видів сосен.

Розраховані значення відповідних статистичних показників, за якими оцінено основні морфолого-таксаційні параметри дерев досліджуваних видів сосен, наведено у табл. 3. За аналізом статистичних показників для дерев досліджуваних видів сосен встановлено, що найбільші значення діаметра стовбура властиві сосні Веймутова (489,1 мм), а найменші - сосні Банкса
(272,3 мм). Для найменшого (мінімального) та найбільшого (максимального) значень цього параметра спостерігається дещо інша тенденція: найменші значення мінімального та максимального діаметра стовбура дерева також притаманні деревам сосни Банкса (96,0 та 420,0 мм відповідно), тоді як найбільше значення мінімального діаметра виявлено у дерев сосни звичайної (299,0 мм), а найбільше значення цього параметра - у дерев сосни Веймутова (987,0 мм).

Табл. 3. Статистики основних морфолого-таксаційних параметрів дерев досліджуваних видів на пробних площах

\begin{tabular}{|c|c|c|c|c|c|c|c|c|c|}
\hline Показник & $d b h$ & $t h$ & $P R_{c r}$ & $V_{c r}$ & $S F_{c r}$ & $B a_{c r}$ & $L e_{c r}$ & $V_{t r}$ & $d_{c r}$ \\
\hline \multicolumn{10}{|c|}{ Сосна чорна } \\
\hline Середнє значення & 373,0 & 19,2 & 27,29 & 90,27 & 102,13 & 13,69 & 5,54 & 1,03 & 5,59 \\
\hline Дисперсія & 88,53 & 3,14 & 18,14 & 78,82 & 61,24 & 3,08 & 3,11 & 0,58 & 1,91 \\
\hline Варіація & 23,74 & 16,33 & 66,46 & 87,31 & 59,96 & 22,53 & 56,09 & 56,41 & 34,12 \\
\hline Мінімальне & 223,0 & 10,5 & 6,7 & 9,0 & 20,1 & 7,7 & 1,7 & 0,2 & 2,9 \\
\hline Максимальне & 538,0 & 22,9 & 70,2 & 249,2 & 220,8 & 17,2 & 14,0 & 2,3 & 9,5 \\
\hline Асиметрія & 0,39 & $-0,98$ & 0,96 & 0,99 & 0,56 & $-0,78$ & 1,54 & 0,81 & 0,45 \\
\hline Ексцес & $-0,52$ & 1,04 & 0,31 & $-0,27$ & $-0,69$ & $-0,74$ & 2,90 & $-0,26$ & $-0,74$ \\
\hline Помилка середньої & 18,46 & 0,65 & 3,78 & 16,43 & 12,77 & 0,64 & 0,65 & 0,12 & 0,40 \\
\hline Показник точності досліду & 4,95 & 3,41 & 13,86 & 18,21 & 12,50 & 4,70 & 11,70 & 11,76 & 7,11 \\
\hline \multicolumn{10}{|c|}{ Сосна Веймутова } \\
\hline Середнє значення & 489,1 & 31,2 & 34,58 & 321,95 & 234,79 & 15,39 & 15,84 & 3,33 & 6,38 \\
\hline Дисперсія & 186,71 & 8,68 & 18,80 & 328,04 & 144,69 & 7,10 & 5,38 & 2,76 & 1,83 \\
\hline Варіація & 38,17 & 27,82 & 54,36 & 101,89 & 61,63 & 46,14 & 33,98 & 82,86 & 28,62 \\
\hline Мінімальне & 110,0 & 11,1 & 5,6 & 17,7 & 43,1 & 3,1 & 5,5 & 0,1 & 2,7 \\
\hline Максимальне & 987,0 & 49,2 & 75,9 & 2147,3 & 805,1 & 33,1 & 28,8 & 14,3 & 9,8 \\
\hline Асиметрія & 0,19 & $-0,62$ & 0,52 & 2,94 & 1,33 & 0,10 & 0,42 & 1,30 & 0,12 \\
\hline Ексцес & $-0,54$ & 0,01 & $-0,83$ & 12,97 & 2,50 & $-0,55$ & $-0,29$ & 2,31 & $-1,00$ \\
\hline Помилка середньої & 22,00 & 1,02 & 2,22 & 38,66 & 17,05 & 0,84 & 0,63 & 0,33 & 0,22 \\
\hline Показник точності досліду & 4,50 & 3,28 & 6,41 & 12,01 & 7,26 & 5,44 & 4,00 & 9,77 & 3,37 \\
\hline \multicolumn{10}{|c|}{ Сосна Банкса } \\
\hline Середнє значення & 272,3 & 22,1 & 23,08 & 117,03 & 123,74 & 9,50 & 12,62 & 0,64 & 5,21 \\
\hline Дисперсія & 67,05 & 4,11 & 13,16 & 67,51 & 53,79 & 2,71 & 3,47 & 0,33 & 1,51 \\
\hline Варіація & 24,62 & 18,59 & 57,02 & 57,69 & 43,47 & 28,55 & 27,53 & 51,34 & 29,01 \\
\hline Мінімальне & 96,0 & 6,4 & 6,4 & 1,6 & 8,7 & 2,4 & 4,0 & 0,0 & 2,9 \\
\hline Максимальне & 420,0 & 28,9 & 58,4 & 304,0 & 277,5 & 15,9 & 21,3 & 1,6 & 8,6 \\
\hline Асиметрія & $-0,36$ & $-2,26$ & 0,86 & 0,40 & 0,09 & $-0,22$ & $-0,23$ & 0,51 & 0,38 \\
\hline Ексцес & 0,53 & 7,05 & 0,06 & $-0,22$ & 0,41 & 0,60 & 0,62 & 0,44 & $-0,70$ \\
\hline Помилка середньої & 9,78 & 0,60 & 1,92 & 9,85 & 7,85 & 0,40 & 0,51 & 0,05 & 0,22 \\
\hline Показник точності досліду & 3,59 & 2,71 & 8,32 & 8,41 & 6,34 & 4,16 & 4,02 & 7,49 & 4,23 \\
\hline \multicolumn{10}{|c|}{ Сосна жорстка } \\
\hline Середнє значення & 377,4 & 25,9 & 20,53 & 264,06 & 196,18 & 12,98 & 12,91 & 1,43 & 4,68 \\
\hline Дисперсія & 115,01 & 2,46 & 17,58 & 281,70 & 113,38 & 3,27 & 2,93 & 0,96 & 2,09 \\
\hline Варіація & 30,48 & 9,50 & 85,65 & 106,68 & 57,79 & 25,21 & 22,70 & 67,07 & 44,71 \\
\hline Мінімальне & 238,0 & 21,4 & 1,0 & 43,4 & 72,3 & 5,9 & 8,0 & 0,5 & 1,1 \\
\hline Максимальне & 665,0 & 30,3 & 72,7 & 1365,5 & 567,6 & 17,2 & 18,0 & 3,9 & 9,6 \\
\hline Асиметрія & 0,94 & $-0,24$ & 1,49 & 2,95 & 1,85 & $-0,69$ & $-0,02$ & 1,32 & 0,53 \\
\hline Ексцес & 0,38 & $-0,53$ & 2,33 & 10,27 & 4,22 & $-0,25$ & $-0,99$ & 1,03 & 0,07 \\
\hline Помилка середньої & 23,48 & 0,50 & 3,59 & 57,50 & 23,14 & 0,67 & 0,60 & 0,20 & 0,43 \\
\hline Показник точності досліду & 6,22 & 1,94 & 17,48 & 21,78 & 11,80 & 5,15 & 4,63 & 13,69 & 9,13 \\
\hline \multicolumn{10}{|c|}{ Сосна звичайна } \\
\hline Середнє значення & 441,5 & 27,3 & 31,04 & 192,59 & 168,54 & 14,31 & 12,98 & 1,95 & 6,13 \\
\hline Дисперсія & 73,15 & 3,20 & 14,76 & 143,08 & 83,28 & 3,11 & 4,35 & 0,75 & 1,45 \\
\hline Варіація & 16,57 & 11,74 & 47,55 & 74,30 & 49,42 & 21,76 & 33,55 & 38,65 & 23,63 \\
\hline Мінімальне & 299,0 & 21,1 & 13,0 & $-5,2$ & 61,3 & 8,6 & 6,9 & 0,7 & 4,1 \\
\hline Максимальне & 541,0 & 32,7 & 63,8 & 554,9 & 356,2 & 22,5 & 23,1 & 3,3 & 9,0 \\
\hline Асиметрія & $-0,45$ & $-0,34$ & 0,83 & 1,23 & 0,95 & 0,88 & 0,67 & $-0,01$ & 0,50 \\
\hline Ексцес & $-1,11$ & $-0,70$ & $-0,21$ & 0,94 & 0,22 & 1,84 & $-0,05$ & $-1,11$ & $-0,73$ \\
\hline Помилка середньої & 15,25 & 0,67 & 3,08 & 29,83 & 17,37 & 0,65 & 0,91 & 0,16 & 0,30 \\
\hline Показник точності досліду & 3,45 & 2,45 & 9,91 & 15,49 & 10,30 & 4,54 & 6,99 & 8,06 & 4,93 \\
\hline
\end{tabular}

Примітка: $d b h$ - діаметр стовбура на висоті $1,3 \mathrm{м}, \mathrm{мм} ; t h$ - загальна висота стовбура, м; $P R_{c r}-$ проекція крони, м²; $V_{c r}-$

об'єм крони, м ${ }^{3} ; S F_{c r}$ - площа поверхні крони, м²; $B a_{c r}$ - висота початку крони, м; $L e_{c r}$ - протяжність крони, м; $f-$ видове число; $V_{t r}-$ об'єм стовбура дерева, м³ $d_{c r}-$ діаметр крони, м.

Найбільші значення середньої висоти серед дерев досліджуваних порід виявлено у сосни Веймутова (31,2 м), а найменші - у сосни чорної (19,2 м). Серед мінімальних значень висоти найменші значення виявлено у дерев сосни Банкса (6,4 м), а найбільше - у сосни жорсткої (21,4 м). Найбільші значення максимальної висоти виявлено у дерев сосни Веймутова (49,2 м), а найменші - у сосни чорної (22,9 м). Значення середніх, 
мінімальних та максимальних значень діаметрів та висот дерев здійснено детальніше, оскільки ці параметри $\epsilon$, певною мірою, вирішальними для формування крони та первинними для моделювання досліджуваних показників крони. Також потрібно відзначити, що середне значення видового числа відрізняється не істотно. Об'єм стовбура $є$ показником, який залежить від повнодеревності стовбура дерева, його висоти та площі поперечного перетину на висоті 1,3 м, який водночас безпосередньо залежить від діаметра стовбура дерева на цій же висоті. Аналізуючи значення середнього об'єму стовбура встановлено, що найбільше значення цього показника характерне деревам сосни Веймутова $\left(3,33 \mathrm{~m}^{3}\right)$, а найменше - для сосни Банкса $\left(0,64 \mathrm{~m}^{3}\right)$.

Серед таких параметрів крони, як діаметр, висота початку крони та іiї протяжність також встановлено різницю як середніх значень, так і діапазону їхніх змін. Найбільші значення діаметра крони виявлено у дерев сосни Веймутова (6,38 м), а найменші - у сосни жорсткої $(4,68$ м); найбільші значення висоти початку крони - у сосни Веймутова (15,39 м), а найменші - у сосни Банкса $(9,50$ м); найбільші значення протяжності крони - у дерев сосни Веймутова (15,84 м), а найменші - у сосни чорної $(5,54$ м). Щодо значень проекції крони, її об'єму та її площі поверхні встановлено таке: найбільші значення площі проекції крони притаманні сосні Веймутова $\left(34,58 \mathrm{~m}^{2}\right)$, а найменші - сосні жорсткій (20,53 м²); найбільших середніх значень об'єму крони набувають дерева сосни Веймутова $\left(321,95 \mathrm{~m}^{3}\right)$, а найменші - сосни чорної $\left(90,27 \mathrm{~m}^{3}\right)$; найбільші середні значення площі поверхні крони виявлено у дерев сосни Веймутова $\left(234,79\right.$ м $\left.^{2}\right)$, а найменші - для сосни чорної $\left(102,13 \mathrm{~m}^{2}\right)$.

Аналізуючи значення коефіцієнта варіації відповідних морфолого-таксаційних параметрів і показників дерев досліджуваних видів сосен встановлено, що практично для усіх видів спостерігається подібна тенденція за величиною цього коефіцієнта. Найменш варіабельним $€$ значення висоти стовбура дерева, далі - за спаданням: висота початку крони, діаметр стовбура, висота до початку крони та ії протяжність. Для цих показників значення коефіцієнта варіації змінюється в межах від $9,50 \%$ для висоти стовбура дерев сосни жорсткої до $56,09 \%$ для діаметра крони дерев сосни чорної. Далі за спаданням розташовуються значення об'єму стовбура дерева, площі поверхні крони, проекції крони та іiі об'єму. Тут значення змінюються в межах від 38,61\% для об'єму стовбура дерева сосни звичайної до 106,68 \% об'єму крони для дерев сосни жорсткої. Насамперед це зумовлено особливостями формування крон деревними породами, морфолого-таксаційними ознаками дерев, типом розміщення та густотою стояння. Результати кореляційного аналізу наведено у табл. 4.

За даними цієї таблиці бачимо, що між проекцією крони, її об'ємом та площею її поверхні та морфологотаксаційними параметрами дерев існує кореляційний зв'язок на рівні, за якого можливе здійснення моделювання залежності між ними. Практично між діаметром стовбура та площею проекції крони значення коефіцієнта кореляції змінюється від 0,64 для дерев сосни Банкса до 0,77 для дерев сосни чорної, між діаметром стовбура та об'ємом крони від 0,50 для дерев сосни жорсткої до 0,77 для дерев сосни чорної та між діаметром стовбура та площею поверхні крони від 0,56 для сосни Банкса до 0,78 для сосни чорної. Водночас значення коефіцієнта кореляції між діаметром крони та проекцією крони становить від 0,73 для дерев сосни жорсткої до 0,99 для дерев сосни чорної, між діаметром крони та її об'ємом від 0,42 для дерев сосни Веймутова до 0,71 сосни чорної та сосни Банкса, між діаметром крони та площею іiї поверхні від 0,63 для дерев сосни жорсткої до 0,75 для дерев сосни чорної.

Табл. 4. Значення коефіцієнтів кореляції між основними морфолого-таксаційними показниками дерев досліджуваних видів

\begin{tabular}{|c|c|c|c|c|c|c|c|c|c|}
\hline $\begin{array}{l}\text { Іоказ- } \\
\text { ники }\end{array}$ & $d b h$ & th & $P R_{c r}$ & $V_{c r}$ & $S F_{c r}$ & $B a_{c r}$ & $L e_{c r}$ & $V_{t r}$ & $d_{c r}$ \\
\hline \multicolumn{10}{|c|}{ Сосна чорна } \\
\hline$d b h$ &, 00 & - & - & - & - & - & - & - & - \\
\hline th & 59 &, 00 & - & 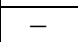 & - & & - & - & - \\
\hline$P R_{c r}$ & 0,77 & 35 & 1,00 & - & - & & - & - & - \\
\hline$V_{c r}$ & 0,77 & 57 & 0,72 & 1,00 & - & & - & & - \\
\hline$S F_{c r}$ & 0,78 & 59 & 0,75 & 0,98 & 1,00 & & & & - \\
\hline$B a_{c r}$ & $-0,03$ & 0,50 & $-0,02$ & $-0,06$ & $-0,04$ & 1,00 & 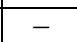 & & - \\
\hline$L e_{c r}$ & 0,63 & 0,51 & 0,37 & 0,64 & 0,63 & $-0,49$ & 1,00 & 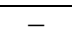 & - \\
\hline$V_{t r}$ & 0,97 & 0,69 & 0,73 & 0,84 & 0,83 & & & 1,00 & - \\
\hline$d_{c r}$ & 0,77 & 0,38 & 0,99 & 0,71 & 0,75 & $-0,03$ & 0,41 & 72 & 1,00 \\
\hline \multicolumn{10}{|c|}{ Сосна Веймутова } \\
\hline$d b h$ & 00 & & - & - & - & 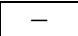 & - & - & - \\
\hline th & 69 & 00 & - & 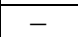 & - & & - & - & - \\
\hline$\overline{P R c r}$ & 0,72 & 41 & 1,00 & - & - & & - & - & - \\
\hline$V c r$ & 0,60 & 5 & 0,41 & 1,00 & & & - & - & - \\
\hline SFcr & 0,69 & & 0,45 & 95 & 1,00 & & & & - \\
\hline Bacr & 0,44 & 79 & 0,30 & $-0,12$ & $-0,05$ & & & - & - \\
\hline Lecr & 0,54 & 0,58 & 0,26 & 0,73 & 0,79 & $-0,05$ & 1,00 & - & - \\
\hline Vtr & 0,94 & 0,68 & 0,64 & 0,57 & 0,65 & 0,45 & 0,51 &, 00 & - \\
\hline$d c r$ & 0,75 & 0,44 & 0,99 & 0,42 & 0,47 & 0,30 & 0,31 & 65 & 1,00 \\
\hline \multicolumn{10}{|c|}{ Сосна Банкса } \\
\hline$d b h$ & 1,00 & - & - & - & - & - & - & - & - \\
\hline th & 0,72 & 1,00 & - & - & - & 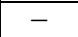 & - & 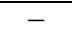 & - \\
\hline PRcr & 0,64 & 0,56 & 1,00 & - & - & - & - & - & - \\
\hline Vcr & 0,53 & 68 & 0,70 & 1,00 & - & - & - & & - \\
\hline SFcr & 0,56 & 0,75 & 0,70 & 0,98 & 1,00 & 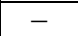 & - & & - \\
\hline Bacr & 0,38 & 0,55 & 0,25 & 0,35 & 0,31 & 1,00 & $\begin{array}{c}- \\
-\end{array}$ & - & - \\
\hline Lecr & 0,55 & 0,76 & 0,47 & 0,53 & 0,64 & 3 & 1 & & - \\
\hline Vtr & 0,97 & 0,68 & 0,69 & 0,59 & 59 & & & 0 & - \\
\hline$d c r$ & 0,67 & 0,59 & 0,99 & 0,71 & 0,71 & 0,27 & 8 & 2 & 1,00 \\
\hline \multicolumn{10}{|c|}{ Сосна жорстка } \\
\hline$d b h$ & 1,00 & - & - & - & - & - & - & - & - \\
\hline th & 0,40 & & 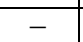 & - & - & & - & - & - \\
\hline$P R c r$ & & &, 00 & 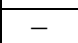 & - & - & - & - & - \\
\hline Vcr & 0,50 & & 6 & 1,00 & & & & & - \\
\hline $\mathrm{cr}$ & 0,59 & & & 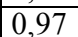 & & & & & - \\
\hline$a c r$ & & & & & & & & & - \\
\hline Lecr & & & & & & & & & - \\
\hline Vtr & 0,98 & 0 & 0,73 & 0,54 & & 0,28 & 7 & & - \\
\hline$c r$ & 0,69 & 0 & 0,97 & 0,56 & 0,68 & $-0,08$ & 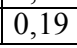 & 71 & 1,00 \\
\hline \multicolumn{10}{|c|}{ Сосна звичайна } \\
\hline$d b h$ & 1,00 & & - & - & - & - & - & - & - \\
\hline th & 0,64 & & & - & - & & 7 & - & - \\
\hline PRcr & 0,70 & 0,57 & 1,00 & - & - & & - & - & - \\
\hline$V c r$ & 0,37 & 0,44 & 0,36 & 1,0 & - & & - & & - \\
\hline SFcr & 0,35 & 0,45 & 0,30 & 0,97 & 1,00 & 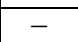 & - & 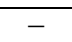 & - \\
\hline Bacr & $-0,05$ & 0,05 & $-0,37$ & $-0,13$ & $-0,08$ & 1,00 & 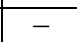 & - & - \\
\hline Lecr & 0,51 & 0,70 & 0,69 & 0,42 & 0,39 & $-0,68$ & 1,00 & - & - \\
\hline Vtr & 0,97 & 0,79 & 0,74 & 0,41 & 0,39 & $-0,06$ & 0,03 & 1,00 & - \\
\hline$d c r$ & 0,74 & 0,56 & 0,99 & 0,38 & 0,33 & $-0,35$ & 0,67 & 0,76 & 1,00 \\
\hline
\end{tabular}

Зважаючи на те, що ці залежності характерні для більшості із досліджуваних видів сосен та фактично $є$ як найвпливовішими на відповідний показник, а також $\epsilon$ такими, які найлегше виміряти, тобто $є$ легкими у практичному застосуванні, вважаємо за доцільне використати їх для моделювання залежності вибраних по- 
казників крон. Після відповідного опрацювання рівнянь найдостовірніше взаємозв'язок описують такі рівняння:

$$
\begin{gathered}
P R_{c r}=a_{0}+a_{1} \cdot d b h \cdot d_{c r}+a_{2} \cdot d b h^{2} \cdot d_{c r}^{2}+\frac{a_{3} \cdot d_{c r}^{3}}{d b h^{3}} ; \\
V_{c r}=a_{0} \cdot d b h \cdot d_{c r}+\frac{a_{1} \cdot d_{c r}^{2}}{d b h^{2}} ;
\end{gathered}
$$

$$
S F_{c r}=a_{0}+a_{1} \cdot d b h \cdot d_{c r}+\frac{a_{2} \cdot d b h^{2}}{d_{c r}^{2}} .
$$

\begin{tabular}{|c|c|c|c|c|c|c|}
\hline \multirow{2}{*}{ Показник } & \multicolumn{4}{|c|}{ Значення коефіцієнтів рівняння } & \multirow{2}{*}{$R^{2}$} & \multirow{2}{*}{ Тип рівняння } \\
\hline & $a_{0}$ & $a_{1}$ & $a_{2}$ & $a_{3}$ & & \\
\hline \multicolumn{7}{|c|}{ Сосна чорна } \\
\hline Площа проекції крони $\left(P R_{c r}\right)$ & $-2,08220$ & 0,11875 & 0,00005 & 1,00008 & 0,82 & $(1)$ \\
\hline Об'єм крони $\left(V_{c r}\right)$ & 0,56140 & $-1429,93818$ & - & - & 0,79 & (2) \\
\hline Площа поверхні крони $\left(S F_{c r}\right)$ & 0,76735 & 0,42637 & 0,13548 & - & 0,76 & (3) \\
\hline \multicolumn{7}{|c|}{ Сосна Веймутова } \\
\hline Площа проекції крони $\left(P R_{c r}\right)$ & 1,70724 & 0,11336 & $-0,00004$ & 0,99990 & 0,80 & $(1)$ \\
\hline Об'єм крони $\left(V_{c r}\right)$ & 0,50195 & 707,62979 & - & - & 0,84 & $(2)$ \\
\hline Площа поверхні крони $\left(S F_{c r}\right)$ & 83,94627 & 0,17002 & 0,23533 & - & 0,74 & (3) \\
\hline \multicolumn{7}{|c|}{ Сосна Банкса } \\
\hline Площа проекції крони $\left(P R_{c r}\right)$ & 0,59985 & 0,12268 & 0,00016 & 1,00008 & 0,80 & $(1)$ \\
\hline Об'єм крони $\left(V_{c r}\right)$ & 0,68983 & 327,72415 & - & - & 0,78 & $(2)$ \\
\hline Площа поверхні крони $\left(S F_{c r}\right)$ & 60,53409 & 0,50707 & $-0,39714$ & - & 0,72 & (3) \\
\hline \multicolumn{7}{|c|}{ Сосна жорстка } \\
\hline Площа проекції крони $\left(P R_{c r}\right)$ & $-1,64541$ & 0,11659 & $-0,00001$ & 0,99995 & 0,81 & (1) \\
\hline Об'єм крони $\left(V_{c r}\right)$ & 1,14106 & 1933,07108 & - & - & 0,79 & $(2)$ \\
\hline Площа поверхні крони $\left(S F_{c r}\right)$ & 112,11988 & 0,49309 & $-0,10820$ & - & 0,80 & (3) \\
\hline \multicolumn{7}{|c|}{ Сосна звичайна } \\
\hline Площа проекції крони $\left(P R_{c r}\right)$ & 12,58747 & $-0,01674$ & 0,00027 & 0,99996 & 0,81 & $(1)$ \\
\hline Об'єм крони $\left(V_{c r}\right)$ & 0,61965 & 901,75345 & - & - & 0,76 & $(2)$ \\
\hline Площа поверхні крони $\left(S F_{c r}\right)$ & 92,43570 & 0,28224 & $-0,04226$ & - & 0,71 & $(3)$ \\
\hline
\end{tabular}

Табл. 5. Параметри рівняння для визначення показників крон досліджуваних видів сосен

Зважаючи на достатньо високі значення коефіцієнтів детермінації відповідних рівнянь залежностей можна стверджувати, що вони описують досліджувані закономірності на достатньому рівні.

Висновки. Отже, проаналізувавши результати дослідження соснових інтродуцентів, можна зробити такі висновки:

1. Показники крон соснових дерев характеризуються значною мінливістю.

2. На величину крони впливають лісівничо-таксаційні показники насадження та морфолого-таксаційні параметри окремого дерева, зокрема серед останніх найвпливовішими є діаметр стовбура та діаметр крони.

3. Технологія ГIC Field-Map дає змогу виконати заміри параметрів крон безпосередньо у насадженні і розрахувати її морфолого-таксаційні показники, зокрема об'єм.

4. Розроблені моделі залежностей адекватно описують емпіричний матеріал 3 високим рівнем апроксимації та характеризуються достатньою статистичною достовірністю.

\section{Перелік використаних джерел}

Buksha, I. F., \& Buksha, M. I. (2013). Primenenie mobilnoi GIStekhnologii Field-Map v lesnom i sadovo-parkovom khoziaistve. Scientific Bulletin of UNFU, 23(5), 28-34. [In Russian].

Data Collector. (2006). Project Manager, Inventory Analyst, Inventory Designer. Ispolzovalas tekhnologiia Field-Map (IFER-Monitoring and Mapping Solutions, s.r.o., www.field-mapping.com), predostavlennaia NLTU Ukrainy v 2006 g. v ramkakh programmy mezhdunarodnogo sotrudnichestva Cheshskoi Respubliki - proekt TekhInLes. [In Russian].

Davies, O., \& Pommerening, A. (2008). The contribution of structural indices to the modelling of Sitka spruce (Picea sitchensis) and birch (Betula spp.) crowns. Forest Ecology and Management, 256, 68-77.

Gromiak, O. Yu., Hrynyk, H. H., \& Yarosh, M. I. (2013). Research of morphological-assessments structure features of pine forests stands in subir site conditions. Scientific Bulletin of UNFU, 23(1), 84-89.
Gromiak, O. Yu., Hrynyk, H. H., Moseychuk, P. P., \& Shishkin, A. V. (2014). Research and Statistical Analysis of Morphological and Assessment Structure of Scotch Pine Forest Stands in Sugrud Type Side Conditions. Scientific Bulletin of UNFU, 24(1), 39-44.

Hadov, K., Horoshko, M. P., \& Korol, M. M. (2003). Modeliuvannia parametriv krony derev v Ukrainskykh Karpatakh. Scientific Bulletin of UkrSFU, 13(3), 264-273. [In Ukrainian].

Horoshko, M. P., Myklush, S. I., \& Khomiuk, P. H. (2004). Biometriia. Lviv: Kamula, 236 p. [In Ukrainian].

Hrynyk, H. H., \& Gromyak, O. Yu. (2014). Modeling of basic morphological indexes of Scots pine trees in pine forest stands of Podilska Upland. Proceedings of the Forestry Academy of Sciences of Ukraine: Collection of Research Papers, 12, 126-134.

Ilkiv, I. S. (2002). Vstanovlennia zalezhnostei mizh morfolohichnymy i taksatsiinymy pokaznykamy derev buka lisovoho metodamy mnozhynnoi rehresii. Scientific Bulletin of UkrSFU, 12(8), 111114. [In Ukrainian].

Peper, P. J., McPherson, E. G., \& Mori, S. M. (2001). Equations for predicting diameter, height, crown width, and leaf area of san joaquin valley street trees. Journal of Arboriculture, 27(6), 306-317.

Pukman, V. V., \& Hrynyk, H. H. (2013). Models dynamics of basic morphological crown indexes of maple-sycamore trees in sycamore forests stands of Ukrainian Carpathians. Scientific Bulletin of UN$F U, 23(17), 58-66$.

Sytnyk, S., Lovynska, V., Lakyda, P., \& Maslikova, K. (2018). Basic density and crown parameters of forest forming species within Steppe zone in Ukraine. Folia Oecologica, 45(2), 82-91. https://doi.org/10.2478/foecol-2018-0009.

Thorpe, H. C., et al. (2010). Competition and tree crowns: A neighborhood analysis of three boreal tree species. Forest Ecology and Management, 259, 1586-1596.

Yuskevych, T. V., Huz, M. M., \& Skrobach, T. B. (2013). Rozpovsiudzhennia ta lisivnycho-taksatsiina kharakterystyka lisovykh nasadzhen za uchastiu sosny chornoi u Zakhidnomu rehioni Ukrainy. Scientific Bulletin of UNFU, 23(13), 73-77. [In Ukrainian].

Yuskevych, T. V., Vytseha, R. R., \& Osadchuk, L. S. (2015). Otsiniuvannia stovburovoho zapasu derevostaniv sosny Banksa ta sosny zhorstkoi v umovakh Zakhidnoho rehionu Ukrainy. Scientific Bulletin of UNFU, 25(4), 17-23. [In Ukrainian]. 
T. V. Yuskevych, R. R. Vytseha, H. H. Hrynyk Ukrainian National Forestry University, Lviv, Ukraine

\section{THE DEPENDENCE OF CROWN INDICATORS ON MORPHOLOGICAL AND TAXONOMIC PARAMETERS OF PINE TREES OF INTRODUCED SPECIES IN WESTERN UKRAINE}

The paper presents the results of the study of the crowns of introduced pine trees in the conditions of the Western region of Ukraine. The purpose of the study is to analyze the dependence of the crowns on the morphological and taxonomic parameters of the introduced species of pine trees in the conditions of the Western region of Ukraine and to perform their modeling. In the course of the study the calculation of the main forest estimated features of test plots was performed according to generally accepted methods in forest taxation. The volume of tree crowns is determined using software modules of GIS Field-Map technology. Basic statistical data and correlation ratios between certain individual features are performed in compliance with the recommendations for statistical data analysis in biological objects. Having conducted the research, we have obtained the following results. Firstly, tree stands with the participation of black pine, eastern white pine, jack pine, pitch pine, and for control of Silver pine. The regularities between the morphological and taxonomic parameters of separate trees and morphological indices of their crowns are analyzed. The average values of the average diameter and height of the tree trunk, crown diameter and height, crown spread, its projection, the volume and area of its surface, as well as trunk volume, have been assessed. The basic statistics of the studied morphological and taxonomic parameters and tree indices are also calculated. In addition, a correlation analysis of the series of corresponding parameters and indicators was made. The selection for the possibility of modeling the dependence of the morphological indicators of crowns on the morphological and taxonomic parameters of trees of the studied species was performed. Therefore, we have drawn the following conclusions. The indicators of pine tree crowns are characterized by considerable variability. The size of the crown is affected by the forest estimated features and morphological and taxonomic parameters of the separate tree, in particular, the most influential ones are the trunk diameter and the crown diameter. Field-Map technology allows performing measurements of crown parameters directly on the plot and calculating its morphological and taxonomic indicators, including volume. The developed dependency models adequately describe empirical material with high level of approximation and are characterized by sufficient statistical reliability. In order to simulate the values of the crown projection area, its volume and the crown surface area, we found trunk diameter and crown diameter of the studied pine species are found to be the most suitable.

Keywords: tree crown; pitch pine; black pine; jack pine; eastern white pine; Field-Map GIS; modeling. 